\title{
IMPLEMENTATION OF COOPERATIVE LEARNING MODEL OF THINK PAIR SQUARE TYPE TO IMPROVE STUDENTS' MATHEMATICS LEARNING OUTCOMES IN CLASS VII SMP NEGERI 3 PEKANBARU
}

\section{PENERAPAN MODEL PEMBELAJARAN KOOPERATIF TIPE THINK PAIR SQUARE UNTUK MENINGKATKAN HASIL BELAJAR MATEMATIKA SISWA KELAS VII SMP NEGERI 3 PEKANBARU}

\author{
Anggi, Nahor Murani Hutapea, Rini Dian Anggraini \\ Pendidikan Matematika, Universitas Riau \\ Email : anggi.anggi@student.unri.ac.id
}

Submitted: (23 April 2020); Accepted: (28 Mei 2020);

Published: (31 Mei 2020)

\begin{abstract}
This research is a classroom action research that aimed to improve the learning process and improve student learning outcomes through the implementation of the Cooperative Learning Model of Think Pair Square type. This research was conducted in class VII ${ }_{1}$ of SMP Negeri 3 Pekanbaru in the odd semester of 2019/2020. The subjects of this study were 40 students consisting of 21 boys and 19 girls. The research was done in two cycles with each cycle consisting of three meetings and once quiz. The research instrument used learning devices and data collection instrument. Learning devices consist of syllabus, lesson plan, student worksheet. Data collection instruments consisted of observation sheets and learning outcomes tests. Based on data analysis of teacher and student activities, it appears that there was an improvement in the learning process after implementation of Cooperative Learning model of Think Pair Square type. The data obtained from the student mathematics learning outcomes test shows that the competence of knowledge increased in the frequency of students achieving minimum mastery criteria (KKM) before action (12 students) to first cycle (26 students) and to second cycle (31 students). The competence of skills increased in the frequency of students achieving KKM from the first cycle (28 students) and to second cycle (37 students). This study results indicated that the implementation of the Cooperative Learning model of think pair square type can improve the learning process and improve students' mathematics learning outcomes of class VII ${ }_{1}$ SMP Negeri 3 Pekanbaru.
\end{abstract}

Keywords : $\quad$ Classroom action research, Cooperative learning model of Think Pair Square type, Mathematics learning outcomes

\section{PENDAHULUAN}

Pembelajaran matematika yang dilaksanakan di sekolah memiliki beberapa tujuan yang dicapai. Adapun tujuan pembelajaran matematika sesuai dengan Kurikulum 2013 yaitu siswa diharapkan dapat: 1) memahami keterkaitan antar konsep dalam pemecahan masalah; 2) menggunakan pola sebagai dugaan dalam penyelesaian masalah dan membuat generalisasi berdasarkan fenomena atau data yang ada; 3) menggunakan penalaran pada sifat, melakukan manipulasi matematika baik dalam penyederhanaan, maupun menganalisa komponen yang ada dalam pemecahan masalah dalam konteks matematika maupun di luar matematika; 4) mengomunikasikan gagasan, penalaran serta mampu menyusun bukti metematika dengan menggunakan kalimat lengkap, simbol, tabel, diagram atau media lain untuk memperjelas keadaan atau masalah; 5) memiliki sikap menghargai kegunaan matematika dalam kehidupan, yaitu memiliki rasa ingin tahu, perhatian dan minat dalam mempelajari matematika, serta sikap ulet dan percaya diri dalam pemecahan masalah; 6) memiliki sikap dan perilaku yang sesuai dengan skor-skor dalam matematika 
dan pembelajarannya; 7) melakukan kegiatankegiatan motorik yang menggunakan pengetahuan matematika; 8) menggunakan alat peraga sederhana maupun hasil teknologi untuk melakukan kegiatan-kegiatan matematika (Kemendikbud, 2014).

Ketercapaian tujuan pembelajaran matematika tersebut dapat dilihat dari hasil belajar matematika yang diperoleh siswa berdasarkan pada Kriteria Ketuntasan Minimal (KKM). Sebagaimana tercantum dalam Permendikbud No. 23 Tahun 2016 tentang Standar Penilaian Pendidikan menyatakan bahwa KKM adalah kriteria ketuntasan belajar yang ditentukan oleh satuan pendidikan. Ketuntasan tersebut dapat dilihat dari skor hasil belajar yang diperoleh setelah mengikuti proses pembelajaran matematika, sehingga siswa dikatakan tuntas dalam belajar matematika apabila siswa telah mencapai KKM yang telah ditetapkan sekolah.

Pada kenyataannya masih ada siswa yang belum dapat mencapai tujuan pembelajaran matematika tersebut. Berdasarkan data yang diperoleh dari guru matematika kelas VII $_{1}$ SMP Negeri 3 Pekanbaru, banyak siswa yang mencapai KKM pada materi Bilangan Bulat adalah 14 dari 40 siswa. Artinya terdapat 26 siswa yang belum menguasai pembelajaran matematika pada materi tersebut. Peneliti melakukan wawancara untuk menemukan permasalahan yang dihadapi guru selama proses pembelajaran. Guru menyatakan bahwa masih banyak siswa yang tidak aktif dalam proses pembelajaran. Saat guru mengajukan pertanyaan hanya beberapa siswa yang aktif untuk menjawab. Banyak dari siswa yang hanya menjadi pendengar saja.

Peneliti melakukan observasi untuk mensingkronkan informasi yang disampaikan guru dengan proses pembelajaran yang ada di kelas. Berdasarkan observasi yang dilakukan, kegiatan pembelajaran dimulai dengan siswa membaca do'a dan dilanjukan dengan memberikan salam kepada guru. Setelah menjawab salam, guru menanyakan kehadiran siswa. Tanpa adanya penyampaian motivasi dan apersepsi, guru langsung melanjutkan kegiatan belajar mengajar dengan penyampaian materi. Pada kegiatan pendahuluan tidak terlihat guru melakukan seperti yang diharapkan Permendikbud No. 22 Tahun 2016. Guru seharusnya menyampaikan apersepsi, tujuan pembelajaran, dan memberi motivasi kepada siswa agar siswa lebih aktif dalam proses pembelajaran.

Pada kegiatan inti, guru menjelaskan materi di papan tulis, kemudian memberi kesempatan kepada siswa untuk mencatat di buku catatan. Namun, tidak semua siswa di dalam kelompok yang mencatat dan memperhatikan penjelasan guru, ada beberapa kelompok yang mengobrol dengan temannya saat pembelajaran sedang berlangsung. Kemudian guru memberikan contoh soal kepada siswa. Sebagian kelompok kurang aktif dalam merespon contoh soal yang diberikan guru. Kelompok yang beranggotakan siswa yang memiliki kemampuan akademis tinggi lebih mendominasi dalam proses pembelajaran. Kemudian guru memberikan tugas kepada siswa berupa soal latihan. Saat mengerjakan soal latihan, tidak semua siswa mengerjakan latihan yang diberikan oleh guru secara mandiri. Terlihat juga bahwa siswa tidak bertanya kepada guru apabila ada soal yang tidak dimengerti. Siswa lebih memilih untuk bertanya kepada teman sekelompoknya dan menunggu jawaban teman sekelompoknya yang sudah selesai kemudian mencatatnya. Setelah mengerjakan soal latihan, guru meminta seorang siswa untuk mengerjakannya di papan tulis. Guru memberikan kesempatan kepada siswa untuk bertanya, namun siswa hanya diam dan guru melanjutkan pembelajaran. Aktivitas yang dilakukan siswa hanya mengikuti alur pembelajaran guru, seperti halnya banyak dari siswa yang hanya menjadi pendengar saja, sehingga pembelajaran hanya berpusat pada guru.

Pada kegiatan penutup, guru bersama siswa menyimpulkan pelajaran pada pertemuan tersebut, guru memberikan PR kemudian guru memberitahukan materi untuk pertemuan berikutnya, serta guru menutup pembelajaran dengan mengucapkan salam.

Berdasarkan hasil observasi, dapat disimpulkan beberapa masalah yang terjadi dalam proses pembelajaran yaitu 
pembelajaran berpusat kepada guru sehingga kurangnya partisipasi siswa pada saat proses pembelajaran berlangsung. Saat guru mengajukan pertanyaan hanya beberapa siswa yang aktif untuk menjawab. Banyak dari siswa yang hanya menjadi pendengar saja. Sedangkan Permendikbud Nomor 65 Tahun 2013 mengamanatkan bahwa proses pembelajaran Kurikulum 2013 pada satuan pendidikan harus diselenggarakan secara interaktif, menyenangkan, menantang, memotivasi siswa untuk berpartisi aktif, serta memberikan ruang yang cukup untuk kreatifitas siswa.

Berdasarkan hasil wawancara dengan siswa, diperoleh informasi bahwa siswa tidak tertarik untuk belajar matematika karena sulit memahami materi pelajaran, sehingga siswa tidak aktif dan menjadi kurang serius dalam proses pembelajaran. Siswa juga mengatakan bahwa terkadang merasa jenuh karena dalam proses pembelajaran hanya mendengarkan penjelasan guru, mencatat yang dijelaskan guru, dan mengerjakan soal latihan. Pada saat mengerjakan soal latihan, siswa memilih menunggu jawaban temannya yang sudah selesai. Siswa lebih senang bertanya kepada temannya dibandingkan bertanya kepada guru. Kondisi ini menyebabkan siswa tidak mandiri dalam mengerjakan soal yang diberikan guru.

Berdasarkan permasalahan yang telah dipaparkan, guna memperbaiki proses pembelajaran dan meningkatkan hasil belajar matematika siswa, perlu diterapkan model pembelajaran yang dapat mengoptimalkan partisipasi siswa dalam proses pembelajaran, dengan memberikan siswa banyak waktu untuk berfikir, berdiskusi dan saling membantu dalam memahami materi pembelajaran. Salah satu upaya yang dapat dilakukan untuk mengatasi permasalahan tersebut adalah dengan menerapkan model Pembelajaran Kooperatif tipe Think Pair Square.

Model Pembelajaran Kooperatif tipe Think Pair Square adalah model pembelajaran yang memadukan kegiatan belajar secara mandiri dan secara berkelompok dengan berlandaskan pada teori konstruktivisme (Karyawati, dkk., 2014). Pada penerapannya, Pembelajaran Kooperatif tipe Think Pair
Square memfasilitasi siswa untuk belajar secara mandiri sehingga dapat mengonstruksi pengetahuannya secara bebas. Selanjutnya pembelajaran ini mengarahkan siswa untuk bekerja sama dengan orang lain, sehingga dapat mengembangkan kemampuan sosialnya seperti belajar mengungkapkan ide yang dimilikinya, menjadi pendengar saat orang lain menyampaikan gagasan, dan memberikan tanggapan atas ide/gagasan orang lain.

Model Pembelajaran Kooperatif tipe Think Pair Square yang dikembangkan oleh Spencer Kagan pada tahun 1933 memberikan kesempatan kepada siswa untuk saling berdiskusi mengemukakan gagasan dan memberikan pemahaman mengenai metode lain yang dapat digunakan untuk menyelesaikan masalah. Ketika dua orang siswa tidak dapat menemukan solusi dari suatu masalah, maka dua orang siswa lain di kelompoknya diharapkan bisa mengemukakan alternatif penyelesaian masalah tersebut. Selain itu, jika kedua pasangan dalam kelompok terkendala menemukan jawaban yang benar, keempat siswa tersebut dapat mengkombinasikan hasil diskusi mereka untuk menemukan solusi terbaik guna menyelesaikan masalah. Melalui tahap thinking (berpikir), pairing (berpasangan), dan square (berempat), siswa diajak untuk berpikir secara mandiri terlebih dahulu mengenai suatu masalah yang diberikan. Berikutnya siswa diarahkan untuk dapat mengomunikasikan dan mendiskusikan jawaban penyelesaian masalah tersebut dengan pasangannya yang selanjutnya jawaban ini akan didiskusikan dengan pasangan lain di kelompoknya.

Pembelajaran Kooperatif tipe Think Pair Square memiliki ciri khas dalam pelaksanaannya. Lie (2010) menyatakan sintaks Pembelajaran Kooperatif tipe Think Pair Square adalah meliputi keenam sintaks pembelajaran kooperatif dan ditambahkan dengan: 1) seluruh siswa ditempatkan guru dalam kelompok yang masing-masing beranggotakan empat orang; 2) guru memberikan pertanyaan atau masalah kepada seluruh kelas; 3) siswa diminta memikirkan penyelesaian masalah tersebut secara individu, menyampaikan gagasan kepada pasangannya, 
kemudian mendiskusikan jawaban terbaik berempat dengan teman satu kelompoknya.

Kelebihan model Pembelajaran

Kooperatif tipe Think Pair Square adalah lebih mengoptimalkan peran aktif siswa dalam proses pembelajaran melalui pemberian waktu kepada setiap siswa untuk memikirkan penyelesaian suatu masalah yang diberikan secara mandiri, kemudian mendiskusikan gagasan yang dimilikinya bersama pasangan dan teman satu kelompoknya. Dengan meningkatnya partisipasi siswa dalam proses pembelajaran, diharapkan juga dapat menunjang peningkatan hasil belajar matematika siswa.

Penerapan model Pembelajaran Kooperatif tipe Think Pair Square untuk meningkatkan hasil belajar matematika siswa telah dilakukan oleh peneliti lain sebelumnya dan memperoleh hasil yang cukup memuaskan. Penelitian yang dilakukan oleh Solfitri \& Heleni (2015) menunjukkan bahwa hasil belajar matematika siswa kelas X3 SMAN 5 Pekanbaru semester genap tahun pelajaran 2011/2012 meningkat setelah mengikuti Pembelajaran Kooperatif tipe Think Pair Square pada materi pokok Trigonometri. Demikian juga halnya penelitian yang dilakukan oleh Sukmawati \& Nasrullah (2017) yang memperoleh hasil yang tidak jauh berbeda, bahwa penerapan model Pembelajaran Kooperatif tipe Think Pair Square pada materi pokok Bangun Ruang Sisi Datar di kelas VIII4 MTs Al Huda Pekanbaru semester genap tahun pelajaran 2012/2013 telah dapat meningkatkan hasil belajar matematika siswa. Mengacu pada teori dan hasil penelitian sebelumnya yang relevan, maka untuk memperbaiki proses pembelajaran dan meningkatkan hasil belajar matematika siswa kelas VII 1 SMP Negeri 3 Pekanbaru semester ganjil tahun pelajaran 2019/2020 pada materi Persamaan dan Pertidaksamaan Linear Satu Variabel diterapkan model Pembelajaran Kooperatif tipe Think Pair Square.

\section{METODE}

Jenis penelitian yang dilakukan adalah Penelitian Tindakan Kelas (PTK). Bentuk PTK dalam penelitian ini adalah PTK kolaboratif, yaitu peneliti dan guru matematika kelas $\mathrm{VII}_{1} \mathrm{SMP}$ Negeri 3 Pekanbaru bekerja sama dalam proses pelaksanaan tindakan. Pelaksanaan tindakan dilakukan oleh peneliti sedangkan guru berperan sebagai pengamat selama proses pembelajaran berlangsung. PTK yang dilakukan terdiri dari dua siklus, masingmasing siklus terdiri dari empata tahap, yaitu perencanaan, pelaksanaan, pengamatan, dan refleksi (Arikunto, dkk., 2015).

Subjek penelitian adalah siswa kelas VII 1 SMP Negeri 3 Pekanbaru semester ganjil tahun pelajaran 2019/2020 sebanyak 40 siswa yang terdiri dari 21 siswa laki-laki dan 19 siswa perempuan dengan tingkat kemampuan akademis yang heterogen. Instrumen penelitian yang digunakan adalah perangkat pembelajaran dan instrumen pengumpul data. Perangkat pembelajaran terdiri dari Silabus, Rencana Pelaksanaan Pembelajaran (RPP), Lembar Aktifitas Siswa (LAS). Instrumen pengumpul data terdiri dari lembar pengamatan aktivitas guru dan siswa serta instrumen penilaian tes hasil belajar. Pengumpulan data dilakukan dengan menggunakan teknik pengamatan dan teknik tes. Pengamatan dilakukan selama proses pembelajaran dan tes dilakukan sebanyak dua kali, masing-masing setelah selesainya tiga kali proses pembelajaran.

Teknik analisa data yang dilakukan adalah teknik analisis deskriptif naratif untuk data kualitatif yang diperoleh dari hasil pengamatan dan teknik analisis statistik deskriptif untuk data kuantitatif yang diperoleh dari hasil tes. Analisis data kualitatif dimulai dengan menelaah seluruh data yang tersedia dari berbagai sumber yaitu lembar pengamatan aktivitas guru dan lembar pengamatan aktivitas siswa sesuai langkahlangkah pada RPP. Kesimpulan yang diperoleh dari deskripsi hasil pengamatan merupakan evaluasi terhadap tindakan yang telah dilakukan untuk melihat apakah ada perbaikan proses pembelajaran.

Analisis data kuantitatif tentang hasil belajar matematika siswa terdiri dari beberapa bagian, yaitu analisis nilai perkembangan individu dan penghargaan kelompok, analisis ketercapaian KKM, analisisi ketercapaian 
KKM indikator, dan analisis ditsribusi frekuensi. Nilai perkembangan individu pada siklus I diperoleh dari selisih nilai skor dasar dan nilai Ulangan Harian (UH) I, dan nilai perkembangan individu pada Siklus II diperoleh dari selisih nilai skor dasar dan Ulangan Harian (UH) II. Ketika nilai perkembangan individu siswa semakin meningkat dan penghargaan kelompok semakin membaik maka dapat dikatakan bahwa telah terjadi peningkatan hasil belajar matematika siswa. Penghargaan kelompok yang diberikan menggunakan kriteria yang disampaikan oleh Mangentje (2013) yang dapat dilihat pada Tabel 1 berikut.

Tabel 1. Kriteria Penghargaan Kelompok

\begin{tabular}{cc}
\hline $\begin{array}{c}\text { Interval } \\
\text { Nilai Kelompok (NK) }\end{array}$ & $\begin{array}{c}\text { Penghargaan } \\
\text { Kelompok }\end{array}$ \\
\hline $15 \leq \mathrm{NK}<20$ & Baik \\
$20 \leq \mathrm{NK}<25$ & Hebat \\
$\mathrm{NK} \geq 25$ & Super \\
\hline
\end{tabular}

Analisis data ketercapaian KKM indikator dilakukan untuk menghitung persentase jumlah siswa yang mencapai KKM pada setiap indikator. Siswa dikatakan mencapai kriteria ketuntasan untuk setiap indikator apabila siswa mencapai lebih atau sama dengan KKM indikator yang telah ditentukan yaitu 75. Jika persentase jumlah siswa yang mencapai KKM indikator meningkat dari skor dasar ke skor UH-I dan UH-II maka dikatakan bahwa tindakan dapat meningkatkan hasil belajar matematika siswa.

Seluruh data hasil belajar matematika siswa disajikan dalam bentuk tabel distribusi frekuensi agar diperoleh gambaran yang jelas mengenai hasil belajar matematika siswa serta dapat melihat apakah terjadi peningkatan atau penurunan hasil belajar sebelum dan sesudah tindakan. Jika jumlah siswa yang berada pada interval di bawah KKM mengalami penurunan atau jumlah siswa yang mencapai interval di atas KKM mengalami peningkatan dari skor dasar ke UH I dan dari skor dasar ke UH II maka dikatakan bahwa tindakan dapat meningkatkan hasil belajar matematika siswa.

\section{HASIL DAN PEMBAHASAN}

Berdasarkan analisis data aktivitas guru dan siswa dapat dikatakan bahwa penerapan model Pembelajaran Kooperatif tipe Think Pair Square mengalami peningkatan pada setiap pertemuan, namun pada siklus I masih terdapat kekurangan yang dilakukan peneliti dan siswa di antaranya dapat dilihat pada Tabel 2 berikut.

Tabel 2. Kekurangan Pelaksanaan Tindakan pada Siklus I

\begin{tabular}{|c|c|}
\hline Kekurangan & $\begin{array}{c}\begin{array}{c}\text { Perbaikan yang } \\
\text { Dilakukan }\end{array} \\
\end{array}$ \\
\hline $\begin{array}{l}\text { Masih rendahnya } \\
\text { respon siswa pada } \\
\text { kegiatan pendahuluan } \\
\text { yaitu pada apersepsi, } \\
\text { penyampaian tujuan } \\
\text { pembelajaran dan } \\
\text { motivasi. }\end{array}$ & $\begin{array}{l}\text { Peneliti memotivasi } \\
\text { siswa agar terlibat } \\
\text { aktif } \\
\text { merespon } \\
\text { pertanyaan peneliti } \\
\text { pada kegiatan } \\
\text { pendahuluan. }\end{array}$ \\
\hline $\begin{array}{ll}\text { Saat pengerjaan LAS } \\
\text { yaitu tahap think, pair } \\
\text { dan square banyak } \\
\text { siswa } & \text { memilih } \\
\text { menyalin } & \text { jawaban } \\
\text { temannya. } & \end{array}$ & $\begin{array}{l}\text { Peneliti memberikan } \\
\text { arahan kepada siswa } \\
\text { tentang pentingnya } \\
\text { mengerjakan LAS } \\
\text { dan menegur siswa } \\
\text { yang hanya } \\
\text { menyalinnya } \\
\text { jawaban } \\
\text { temannya. }\end{array}$ \\
\hline
\end{tabular}

Pada tahap evaluasi siswa masih belum inisiatif untuk memberikan tanggapan.

Peneliti menunjuk kelompok yang memberi tanggapan jika tidak ada kelompok yang bersedia.

Berdasarkan hasil Peneliti ulangan harian $\mathrm{I}$, mengingatkan masih banyak siswa kembali agar siswa yang tidak membuat membuat kesimpulan dari hasil kesimpulan pada pemecahan masalah akhir pekerjaan yang mereka peroleh. mereka.

Sejalan dengan perbaikan yang dilakukan oleh peneliti pada Siklus II, hasil belajar matematika juga mengalami peningkatan. Salah satu aspek peningkatan hasil belajar matematika adalah nilai perkembangan individu siswa yang dapat dilihat pada Tabel 3 . 
Tabel 3. Nilai Perkembangan Individu Siswa

\begin{tabular}{ccccc}
\hline \multirow{2}{*}{$\begin{array}{c}\text { Nilai } \\
\text { Perkem } \\
\text { bangan }\end{array}$} & \multicolumn{2}{c}{ Siklus I } & \multicolumn{2}{c}{ Siklus II } \\
\cline { 2 - 5 } & $\begin{array}{c}\text { Jumlah } \\
\text { Siswa }\end{array}$ & $\begin{array}{c}\text { Persen- } \\
\text { tase }\end{array}$ & $\begin{array}{c}\text { Jumlah } \\
\text { Siswa }\end{array}$ & $\begin{array}{c}\text { Persen- } \\
\text { tase }\end{array}$ \\
\hline 5 & 5 & $12,5 \%$ & 1 & $2,5 \%$ \\
10 & 2 & $5,0 \%$ & 3 & $7,5 \%$ \\
20 & 12 & $30,0 \%$ & 5 & $12,5 \%$ \\
30 & 21 & $52,5 \%$ & 31 & $77,5 \%$ \\
\hline
\end{tabular}

Berdasarkan Tabel 3 terlihat bahwa jumlah siswa yang menyumbangkan nilai perkembangan 5 dan 10 pada siklus I ada tujuh siswa yang berarti nilai pada UH-I lebih rendah dari skor dasar. Sedangkan pada siklus II, jumlah siswa yang menyumbangkan nilai perkembangan 5 dan 10 berkurang menjadi empat siswa. Hal ini berarti jumlah siswa yang nilai UH II-nya lebih rendah dari skor dasar berkurang. Pada siklus I siswa yang menyumbangkan nilai perkembangan 20 dan 30 sebanyak 33 siswa. Pada siklus II, siswa yang menyumbangkan nilai perkembangan 20 dan 30 bertambh menjadi 36 siswa. Dengan kata lain, lebih banyak siswa yang mengalami peningkatan nilai UH daripada jumlah siswa yang mengalami penurunan nilai $\mathrm{UH}$. Berdasarkan kriteria peningkatan hasil analisis nilai perkembangan individu, maka dapat dikatakan terjadi peningkatan hasil belajar matematika siswa.

Berdasarkan nilai perkembangan individu, dapat ditentukan penghargaan kelompok yang dapat dilihat pada Tabel 4 berikut.

Tabel 4. Penghargaan Kelompok pada Siklus I dan Siklus II

\begin{tabular}{ccccc}
\hline & \multicolumn{2}{c}{ Siklus I } & \multicolumn{2}{c}{ Siklus II } \\
\cline { 2 - 5 } Kel & $\begin{array}{c}\text { Skor } \\
\text { Perkem } \\
\text { bangan } \\
\text { Kel }\end{array}$ & $\begin{array}{c}\text { Peng- } \\
\text { hargaan }\end{array}$ & $\begin{array}{c}\text { Skor } \\
\text { Perkem } \\
\text { bangan } \\
\text { Kel }\end{array}$ & $\begin{array}{c}\text { Peng- } \\
\text { hargaan }\end{array}$ \\
\hline A & 22,5 & Hebat & 27,5 & Super \\
B & 21,25 & Hebat & 27,5 & Super \\
C & 25 & Super & 30 & Super \\
D & 21,25 & Hebat & 25 & Super \\
E & 22,5 & Hebat & 25 & Super \\
F & 21,25 & Hebat & 23,75 & Hebat \\
G & 25 & Super & 27,5 & Super \\
H & 25 & Super & 30 & Super \\
I & 21,25 & Hebat & 22,5 & Hebat \\
J & 23,75 & Hebat & 25 & Super \\
\hline
\end{tabular}

Dari Tabel 4 terlihat bahwa pada siklus I hanya tiga kelompok yang mendapat penghargaan Super mengalami peningkatan pada siklus II menjadi delapan kelompok. Hal ini menunjukan bahwa terjadinya peningkatan nilai perkembangan setiap individu yang mengakibatkan skor perkembangan kelompok menjadi meningkat juga. Berdasarkan analisis nilai perkembangan kelompok, maka dapat dikatakan terjadi peningkatan hasil belajar.

Hasil belajar matematika siswa berdasarkan analisis ketercapaian KKM pengetahuan dapat dilihat pada Tabel 5.

Tabel 5. Ketercapaian KKM Pengetahuan

\begin{tabular}{lccc}
\hline & $\begin{array}{c}\text { Skor } \\
\text { Dasar }\end{array}$ & UH I & UH II \\
\hline $\begin{array}{l}\text { Jumlah siswa } \\
\text { mencapai } \\
\text { KKM }\end{array}$ & 12 & 26 & 31 \\
\hline Persentase & $30 \%$ & $65 \%$ & $77,5 \%$ \\
\hline
\end{tabular}

Berdasarkan Tabel 5 terlihat bahwa pada skor dasar (sebelum tindakan) hanya 30\% siswa yang mencapai KKM dan terjadi peningkatan setelah tindakan yaitu pada UH-I dan UH-II, persentase siswa yang mencapai KKM meningkat menjadi $65 \%$ dan $77,5 \%$. Ketercapaian KKM Keterampilan dapat dilihat pada Tabel 6.

Tabel 6. Ketercapain KKM Keterampilan

\begin{tabular}{lcc}
\hline & UH I & UH II \\
\hline $\begin{array}{l}\text { Jumlah siswa yang } \\
\text { mencapai KKM }\end{array}$ & 28 & 37 \\
\hline Persentase & $70 \%$ & $92,5 \%$ \\
\hline
\end{tabular}

Pada Tabel 6 terlihat bahwa persentase siswa yang mencapai KKM keterampilan pada UH-I hanya 28 siswa dan kemudian pada UHII menjadi 37 siswa. Menurut kriteria keberhasilan tindakan hal ini juga telah menunjukan terjadinya peningkatan hasil belajar.

Secara lebih rinci, peneliti juga melihat ketercapaian KKM indikator pengetahuan dan keterampilan. Ketercapaian KKM siswa pada indikator pengetahuan disajikan pada Tabel 7 dan Tabel 8 .

Tabel 7. Ketercapaian KKM Indikator Pengetahuan pada Siklus I

\begin{tabular}{clcc}
\hline No & $\begin{array}{c}\text { Indikator } \\
\text { Pencapaian } \\
\text { Kompetensi }\end{array}$ & $\begin{array}{c}\text { Jumlah } \\
\text { Siswa }\end{array}$ & $\begin{array}{c}\text { Persen-tase } \\
(\%)\end{array}$ \\
\hline 1 & $\begin{array}{l}\text { Menentukan } \\
\text { kalimat terbuka } \\
\text { dan kalimat } \\
\text { tertutup }\end{array}$ & 35 & 87,5 \\
& & & \\
\end{tabular}




\begin{tabular}{|c|c|c|c|}
\hline 2 & $\begin{array}{l}\text { Mengubah } \\
\text { masalah yang } \\
\text { berkaitan dengan } \\
\text { persamaan linear } \\
\text { satu variabel }\end{array}$ & 35 & 87,5 \\
\hline 3 & $\begin{array}{l}\text { Menentukan } \\
\text { penyelesaian } \\
\text { persamaan linear } \\
\text { menggunakan } \\
\text { operasi } \\
\text { penjumlahan dan } \\
\text { pengurangan }\end{array}$ & 29 & 72,5 \\
\hline 4 & $\begin{array}{l}\text { Menentukan } \\
\text { penyelesaian } \\
\text { persamaan linear } \\
\text { menggunakan } \\
\text { operasi perkalian } \\
\text { dan pembagian }\end{array}$ & 22 & 55 \\
\hline
\end{tabular}

Dari Tabel 7 dapat dilihat bahwa masih ada siswa yang tidak mencapai KKM untuk setiap indikator. Pada indikator pertama dan kedua, siswa belum mencapai KKM dikarenakan kurang teliti dalam menjawab soal dan tidak menuliskan alasan dari jawaban mereka. Pada indikator ketiga dan keempat, siswa yang belum mencapai KKM dikarenakan siswa belum memahami konsep menentukan penyelesaian persamaan linear satu variabel dalam bentuk operasi penjumlahan, pengurangan, perkalian dan pembagian.

Tabel 8. Ketercapaian KKM Indikator Pengetahuan pada Siklus II

\begin{tabular}{|c|c|c|c|}
\hline No & $\begin{array}{c}\text { Indikator } \\
\text { Pencapaian } \\
\text { Kompetensi }\end{array}$ & $\begin{array}{c}\text { Jumlah } \\
\text { Siswa }\end{array}$ & $\begin{array}{c}\begin{array}{c}\text { Persen } \\
\text { tase } \\
(\%)\end{array} \\
\end{array}$ \\
\hline 1 & $\begin{array}{l}\text { Mengubah } \\
\text { masalah yang } \\
\text { berkaitan dengan } \\
\text { pertidaksamaan } \\
\text { linear satu } \\
\text { variabel menjadi } \\
\text { model } \\
\text { matematika }\end{array}$ & 38 & 95 \\
\hline 2 & $\begin{array}{l}\text { Menentukan } \\
\text { penyelesaian } \\
\text { pertidaksamaan } \\
\text { linear satu } \\
\text { variabel } \\
\text { menggunakan } \\
\text { operasi } \\
\text { penjumlahan dan } \\
\text { pengurangan }\end{array}$ & 34 & 85 \\
\hline
\end{tabular}

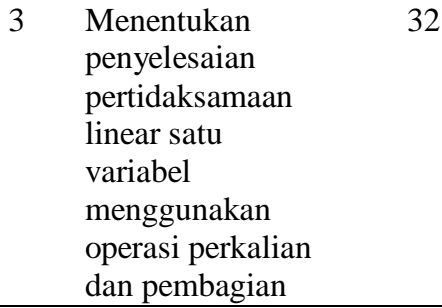

Dari Tabel 8 dapat dilihat bahwa siswa yang tidak mencapai KKM pada setiap indikator semakin berkurang dari UH-I. Siswa yang tidak mencapai KKM terbanyak adalah pada indikator kedua. Hal ini disebabkan beberapa siswa belum memahami konsep menentukan penyelesaian pertidaksamaan linear satu variabel dalam bentuk operasi penjumlahan, pengurangan, perkalian dan pembagian.

Analisis ketercapaian KKM indikator keterampilan pada Siklus I dapat dilihat pada Tabel 9 berikut.

Tabel 9. Ketercapaian KKM Indikator Keterampilan pada Siklus I

\begin{tabular}{clcc}
\hline No & $\begin{array}{l}\text { Indikator } \\
\text { Keterampilan }\end{array}$ & $\begin{array}{c}\text { Jumlah } \\
\text { Siswa }\end{array}$ & $\begin{array}{c}\text { Persen- } \\
\text { tase } \\
(\%)\end{array}$ \\
\hline 1 & $\begin{array}{l}\text { Menuliskan } \\
\text { diketahui dan } \\
\text { ditanya }\end{array}$ & 39 & 97,5 \\
& & \\
\end{tabular}

$2 \begin{aligned} & \text { Menuliskan } \\ & \text { model } \\ & \text { matematika }\end{aligned}$

\begin{tabular}{ccccc}
3 & Menghitung & 18 & 45 \\
\hline & Dari Tabel & 9 & dapat & dilihat \\
bahwa
\end{tabular}
persentase ketercapaian KKM indikator keterampilan terendah yaitu $45 \%$ pada indikator ketiga yaitu menghitung. Hal ini disebabkan siswa masih kurang teliti dalam melakukan perhitungan. Persentase pencapaian KKM indikator tertinggi yaitu $97,5 \%$ pada indikator pertama yaitu menuliskan diketahui dan ditanya. Tidak terdapat persentase pencapaian KKM indikator keterampilan $100 \%$ pada UH-I. Persentase ketercapaian KKM indikator keterampilan pada Siklus II dapat dilihat pada Tabel 10. 
Tabel 10. Persentase Ketercapaian KKM Indikator Keterampilan Siklus II

\begin{tabular}{clcc}
\hline No & $\begin{array}{l}\text { Indikator } \\
\text { Keterampilan }\end{array}$ & $\begin{array}{c}\text { Jumlah } \\
\text { Siswa }\end{array}$ & $\begin{array}{c}\text { Persen- } \\
\text { tase (\%) }\end{array}$ \\
\hline 1 & $\begin{array}{l}\text { Menuliskan } \\
\text { diketahui dan } \\
\text { ditanya }\end{array}$ & 39 & 97,5 \\
2 & $\begin{array}{l}\text { Menuliskan } \\
\text { model } \\
\text { matematika }\end{array}$ & 39 & 97,5 \\
& & \\
\end{tabular}

3 Menghitung
23 57,5

Dari Tabel 10 dapat dilihat bahwa persentase ketercapaian KKM indikator keterampilan terendah yaitu $57,5 \%$ pada indikator ketiga yaitu menghitung. Hal ini disebabkan siswa masih kurang teliti dalam melakukan perhitungan. Persentase pencapaian KKM indikator tertinggi yaitu $97,5 \%$ pada indikator pertama dan kedua.

Untuk mengetahui penyebaran skor hasil belajar matematika yang diperoleh siswa, peneliti melakukan analisis distribusi frekuensi ketercapaian KKM pada kompetensi pengetahuan dan keterampilan yang disajikan pada Tabel 11 dan Tabel 12.

Tabel 11. Distribusi Frekuensi Hasil Belajar Matematika Siswa pada Kompetensi Pengetahuan

\begin{tabular}{cccc}
\hline Interval & \multicolumn{3}{c}{ Frekuensi Siswa } \\
\cline { 2 - 4 } Skor & $\begin{array}{c}\text { Skor } \\
\text { Dasar }\end{array}$ & $\begin{array}{c}\text { Skor } \\
\text { UH-I }\end{array}$ & $\begin{array}{c}\text { Skor } \\
\text { UH-II }\end{array}$ \\
\hline $10-22$ & 6 & 0 & 0 \\
$23-35$ & 0 & 0 & 0 \\
$36-48$ & 2 & 1 & 0 \\
$49-61$ & 9 & 2 & 2 \\
$62-74$ & 11 & 11 & 7 \\
$75-87$ & 11 & 15 & 6 \\
$88-100$ & 1 & 11 & 25 \\
\hline$\sum \mathbf{f}$ & 40 & 40 & 40 \\
\hline
\end{tabular}

Berdasarkan Tabel 11 terlihat bahwa terjadi peningkatan hasil belajar siswa dari sebelum tindakan (skor dasar), ke Siklus I (UH-I), dan ke Siklus II (UH-II). Sebelum tindakan jumlah siswa yang belum mencapai KKM sebanyak 28 orang. Pada Siklus I dan II menurun menjadi 15 siswa dan 9 siswa. Sebaliknya, jumlah siswa yang mencapai KKM mengalami peningkatan, dari 12 siswa
(30\%) sebelum tindakan, menjadi 26 siswa (65\%) pada Siklus I, dan 31 siswa $(77,5 \%)$ pada Siklus II. Data tersebut menunjukkan bahwa setelah tindakan terjadi peningkatan hasil belajar atau terjadi perubahan hasil belajar menjadi lebih baik yang ditandai dengan meningkatnya jumlah siswa yang mencapai KKM setelah dilaksanakan tindakan.

Tabel 12. Distribusi Frekuensi Hasil Belajar Matematika Siswa pada Kompetensi Keterampilan

\begin{tabular}{ccc}
\hline \multirow{2}{*}{ Interval } & \multicolumn{2}{c}{ Frekuensi Siswa } \\
\cline { 2 - 3 } & Skor UH-I & Skor UH-II \\
\hline $10-22$ & 0 & 0 \\
$23-35$ & 1 & 0 \\
$36-48$ & 2 & 0 \\
$49-61$ & 9 & $!$ \\
$62-74$ & 0 & 2 \\
$75-87$ & 13 & 6 \\
$88-100$ & 15 & 31 \\
\hline$\sum \mathbf{f}$ & 40 & 40 \\
\hline
\end{tabular}

Berdasarkan Tabel 12 terlihat bahwa terjadi peningkatan jumlah siswa yang mencapai KKM pada kompetensi keterampilan dari Siklus I ke Siklus II. Jumlah siswa yang mencapai KKM pada Siklus I sebanyak 28 orang $(70 \%)$ mengalami peningkatan pada Siklus II menjadi 37 orang $(92,5 \%)$. Data tersebut menunjukkan bahwa setelah tindakan terjadi peningkatan hasil belajar atau terjadi perubahan hasil belajar menjadi lebih baik pada kompetensi keterampilan.

Dari analisis data yang dilakukan, model Pembelajaran Kooperatif tipe Think Pair Square dapat memperbaiki proses pembelajaran dan meningkatkan hasil belajar matematika siswa kelas VII $_{1}$ SMP Negeri 3 Pekanbaru semester ganjil tahun pelajaran 2018/2019 pada KD 3.6 Menjelaskan persamaan dan pertidaksamaan linear satu variabel dan penyelesaiannya dan KD 4.6 Menyelesaikan masalah yang berkaitan dengan persamaan dan pertidaksamaan linear satu variabel. Hasil penelitian ini sejalan dengan hasil penelitian yang dilakukan Sukmawati dan Nasrullah (2017) yang menunjukkan bahwa penerapan model Pembelajaran Kooperatif Pendekatan Struktural Think Pair Square pada materi pokok Bangun Ruang Sisi Datar di kelas VIII4 MTs Al Huda Pekanbaru semester 
genap tahun pelajaran 2012/2013 telah dapat meningkatkan hasil belajar matematika siswa. Begitu juga dengan penelitian yang dilakukan oleh Anwar dan Ugi (2017) yang memeroleh hasil bahwa prestasi belajar matematika siswa kelas X.8 SMA Negeri 1 Baubau meningkat melalui penerapan model Pembelajaran Kooperatif Tipe Think Pair Square.

\section{SIMPULAN}

Berdasarkan hasil penelitian yang telah peneliti lakukan dapat disimpulkan bahwa model Pembelajaran Kooperatif tipe Think Pair Square dapat memperbaiki proses pembelajaran dan meningkatkan hasil belajar matematika siswa kelas $\mathrm{VII}_{1}$ SMP Negeri 3 Pekanbaru semester ganjil tahun pelajaran 2018/2019 pada KD 3.6 Menjelaskan persamaan dan pertidaksamaan linear satu variabel dan penyelesaiannya, dan KD 4.6 Menyelesaikan masalah yang berkaitan dengan persamaan dan pertidaksamaan linear satu variabel.

\section{REKOMENDASI}

Berdasarkan pembahasan dan kesimpulan dari penelitian ini, peneliti mengajukan beberapa rekomendasi dalam penerapan model Pembelajaran Kooperatif tipe Think Pair Square pada pembelajaran matematika, di antaranya:

1. Penerapan model Pembelajaran Koooperatif tipe Think Pair Square (TPS) dapat dijadikan salah satu alternatif model pembelajaran yang dapat diterapkan untuk memperbaiki proses pembelajaran dan meningkatkan hasil belajar matematika siswa.

2. Guru/peneliti lebih memotivasi siswa untuk dapat memperhatikan penjelesan dari kelompok lain selama proses pembelajaran agar siswa lebih aktif dalam proses pembelajaran.

3. Guru/peneliti harus terampil dalam mengelola kelas dan waktu selama proses pembelajaran agar waktu yang telah direncanakan sesuai dengan pelaksanaan pembelajaran.

\section{DAFTAR PUSTAKA}

Anwar \& Ugi, L.E. (2017). Penerapan Model Pembelajaran Kooperatif Tipe Think Pair Square pada materi ruang dimensi tiga untuk meningkatkan prestasi belajar matematika siswa kelas X SMA Negeri 1 Baubau. JP3M (Jurnal Penelitian Pendidikan dan Pengajaran Matematika), 3(1), 1-12

Arikunto, S., Suhardjono, \& Supardi. (2015). Penelitian tindakan kelas. Bumi Aksara

Karyawati, N.K., Murda, I.N., \& Widiana, I.W. (2014). Pengaruh model pembelajaran kooperatif tipe Think Pair Square (TPS) berbantuan kartu kerja terhadap hasil belajar matematika. Jurnal Mimbar PGSD Universitas Pendidikan Ganesha, 2(1), 1-10

Kemendikbud. (2013). Salinan Lampiran Permendikbud No. 65 Tahun 2013 Tentang Standar Proses. Kemendikbud

Kemendikbud. (2014). Salinan Lampiran Permendikbud No. 58 Tahun 2014 Tentang Kurikulum 2013 Sekolah Menengah Pertama/Madrasah Tsanawiyah. Kemendikbud

Kemendikbud. (2016). Salinan Lampiran Permendikbud No. 22 Tentang Standar Proses Pendidikan Dasar dan Menengah. Kemendikbud

Kemendikbud. (2016). Salinan Lampiran Permendikbud No. 23 Tentang Standar Penilaian Pendidikan. Kemendikbud

Lie, A. (2010). Cooperative learning: Mempraktikkan cooperative learning di ruang-ruang kelas. Grasindo

Mangentje, Y.M. (2013). Penerapan model kooperatif tipe STAD (Student Team Achievement Division) untuk meningkatkan hasil belajar siswa dalam pembelajaran IPS Kelas IV SDN Silampayang. Jurnal Kreatif Tadulako Online, 1(3), 106-117 
Volume 2, Nomor 2, Mei 2020

DOI: https://doi.org/10.33578/prinsip.v2i2.52

jprinsip.ejournal.unri.ac.id

Solfitri, T., \& Heleni, S. (2015). Penerapan model pembelajaran kooperatif tipe Think Pair Square untuk meningkatkan hasil belajar matematika siswa kelas $\mathrm{X}_{3}$ SMA Negeri 5 Pekanbaru. Al-Khwarizmi: Jurnal Pendidikan Matematika dan Ilmu Pengetahuan Alam, 3(1), 33-50
Sukmawati, S., \& Nasrullah, A. (2017). Penerapan model pembelajaran kooperatif pendekatan struktural Think Pair Square untuk meningkatkan hasil belajar matematika siswa. JPPM (Jurnal Penelitian dan Pembelajaran Matematika), 10(1), 115-124. http://dx.doi.org/10.30870/jppm.v10i1.12 04 